\title{
هوالة القنو
}

Journal of Arts, Literature, Humanities and Social Sciences www.jalhss.com

\section{تأثير إضافة البروبيوتكأ على صورة دهون الدام في الفئران المصابة بارتفاع مستوى الكوليستيرول}

يشير النمو المتزايد للأدلة والثو اهد إلى أن بكتيريا البروبيوتلك كمكل غئائي في الألبان المتخمرة يعمل تم أستخدام جنسين من بكتبريا البروبيوتلك هما Lactobacillus and Bifidobacterium) كبادئ حيوي في أحد منتجات الألبان المتخمرة "الرايب" بمستوى أعداد يصل إلى "107 CFU/ml" وذلك لأختبار تأثثير هما المفيد على صورة دهون الدم في الفئران المصابة بأرتفاع مستوى الكوليستيرول في الدم. هذه الفئران كانت قد

أخضعت لنظام غذائي مفرط في الكوليستيرول يحتوي على وجبات غذائية عالية الكوليستيرول لمدة شهرين. أثنارت النتائج إلى أن بكتيريا البروبيوتلك أدت إلى خفض معنوي لمستوى الكوليستيرول الكلي (TC) والجليسريدات الثثلثية (TG) والكوليستيرول المنخفض الكثافة LDL)-cholesterol) والكوليستيرول المنخفض الكثافة جداً (VLDL)- cholesterol). كما أدى كذلك وبدرجة معنوية إلى رفع مسنوى الكوليستيرول المرتفع الكثافة HDL)-cholesterol بعد أستخدام المكل الغذائي "بكتيريا البروبيوتلك" في النظام الغذائي للفئر ان المصابة بأرتفاع مستوى الكوليستيرول في الدم.

ومن ثم فإن هذه النتائج تشير إلى فائدة تناول منتجات الألبان المتخمرة لتحسين الوقاية من أمر اض القلب. 


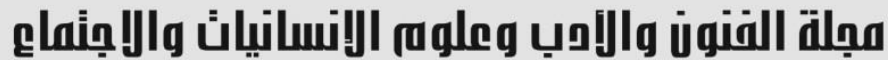

Journal of Arts, Literature, Humanities and Social Sciences www.jalhss.com

\section{Influence of Probiotics Supplementation on the Lipid Profile of Hypercholesterolemic Rats}

\author{
Dr. Amal Mohammed Allbban \\ Assistant Professor of Applied Nutrition - College of Education \\ Umm Al-Qura University - Kingdom of Saudi Arabia \\ Email: mh2432004@gmail.com
}

\begin{abstract}
Accelerating growth of the evidences refers that dietary supplementation with probiotic bacteria in fermented milk improves the lipid profile. Two genera of probiotics bacteria as bio-starters at the level of " $10^{7} \mathrm{CFU} / \mathrm{ml}$ " in fermented milk (Lactobacillus and Bifidobacterium) were used to examine their beneficial effect on the lipid profile of hypercholesterolemic rats which were administered for feeding on high cholesterol diet for two months. Significant going down of the serum total cholesterol (TC), triacylglycerol (TG), low-density lipoprotein (LDL)-cholesterol levels, and very low-density lipoprotein (VLDL)-cholesterol levels, but scale-up of high-density lipoprotein (HDL)-cholesterol were noticed after dietary supplement with probiotic bacteria in hypercholesterolemic rats. Hence, this indicates to the useful of fermented milk for improving the prevention of cardiovascular disease.
\end{abstract}

Keywords: probiotics, cholesterol, blood lipids. 


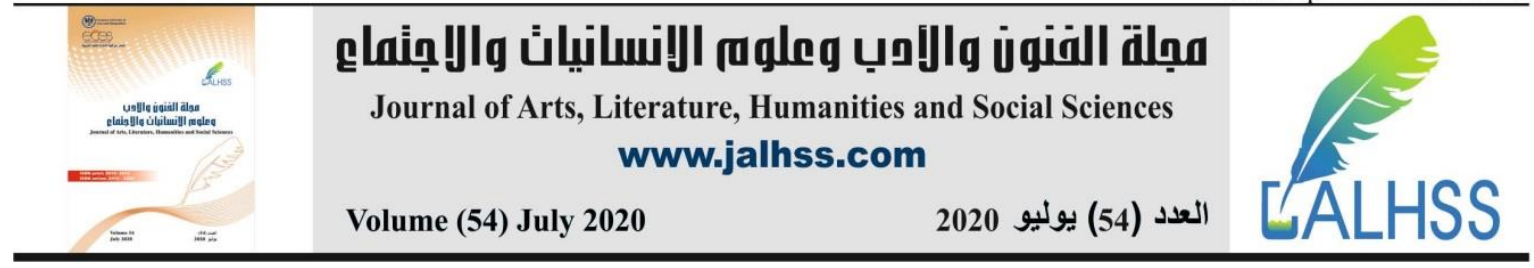

\section{INRODUCATION}

The joint FAO/WHO of the United Nations drafted definition of probiotics as" live microorganisms which, when administered in adequate amounts, confer a health benefit on the host" in 2001, (FAO/WHO, 2001).

Numerous probiotic microorganisms (e.g. Lactobacillus and Bifidobacterium) groups are used as dietary supplements in food, particularly fermented dairy products (De Vrese and Schrezenmeir, 2008). Probiotic products are available in many different forms all over the world, including pills, powders, foods, dairy products, and infant formula (Sanders, 2008).

Hypercholesterolemia is a common cause for a lot of diseases, as well there is strong correlation between the increases of serum cholesterol concentration and increases the occurrence of cardiovascular disease (Davis et al., 1990 and Artham et al., 2008).

Xiao et al., (2003) used Supplement of milk-yogurts fermented with Bifidobacterium to treat albino hypercholesterolemic rats and healthy adult male volunteers; he succeeded to decrease their lipid parameters.

Therefore, use of fermented milk like Rayeb "Laban" as probiotics dietary supplement which has been natural and safe properties could be helpful plan for the prevention of cardiovascular risk via probiotic strains that have cholesterol-lowering effects.

\section{MATERIALS AND METHODS Materials:}

- Rayeb "Laban": Natural Cow's Milk containing two genera of probiotics bacteria as bio-starters (Lactobacillus and Bifidobacterium) at the level of "10 $0^{7} \mathrm{CFU} / \mathrm{ml} "$ at least. The viabilities of the administered strains were confirmed. The Rayeb "Laban" was purchased from a local market.

- Rats: A total of eighteen adult male albino rats, Sprague Dawley strain, weighting (140-150 g) were obtained from the Laboratory Animals Colony.

- Chemicals: Standard diet formula "Casein, cellulose, vitamins and minerals", microbial media, chemicals and kits used throughout the present study are of analytical reagent grade, were obtained from a supplier of (Merck KGaA, Darmstadt, Germany and Sigma-Aldrich, US).

\section{Methods:}

Biological Experiment Design:

Eighteen male albino rats (Sprague-Dawley strain) weighting (140 - $150 \mathrm{~g})$ were housed in well-aerated wire cages. The animals were remained alive at $23-25^{\circ} \mathrm{C}$ with a cycle of 12-h light/12-h dark. The rats were taking in standard diet and also water for one week to be adaptable during the experimental period. Standard diet was synthesized as reported by Reeves et al., (1993). 


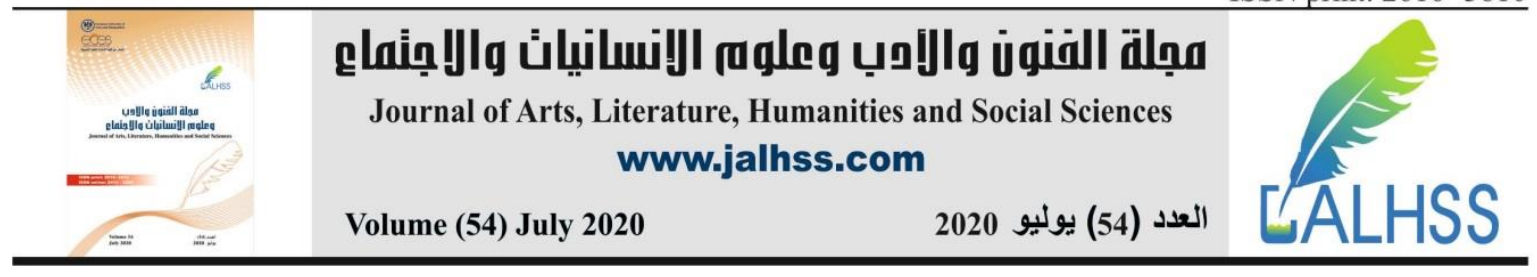

The basal diet ( $\mathrm{g} / \mathrm{kg}$ diet) is composed of $140 \mathrm{~g}$ of casein (> $80 \%$ protein), $100 \mathrm{~g}$ of sucrose , $40 \mathrm{~g}$ of corn oil , $50 \mathrm{~g}$ of cellulose, $35 \mathrm{~g}$ of minerals mixture, $10 \mathrm{~g}$ of vitamins mixture, $1.8 \mathrm{~g}$ of L-cystine, $2.5 \mathrm{~g}$ of choline bitartrate and the remainder is corn starch.

After the adaptation period, the eighteen rats were randomly divided into three groups, (6 rats each):

Group (l) continued to be fed on the basal diet for another eight weeks and kept as a control negative group (normal rats).

Group (2) was fed on hypercholesterolemic diet which consisted of (basal diet, plus $1 \%$ cholesterol, $0.25 \%$ bile salt and $15 \%$ beef tallow) for eight weeks as a control positive (Zulet, et al., 1999).

Group (3) was fed on hypercholesterolemic diet and given orally one ml daily of the Rayeb "Laban" which containing two genera of probiotics bacteria as bio-starters (Lactobacillus and Bifidobacterium) at the level of "10 $70^{7} \mathrm{CFU} / \mathrm{ml} "$ at least, for eight weeks.

At the end of eight weeks of the experimental period, all rats were sacrificed after fasting overnight.

Collection of blood:

At the end of the experiment, all animals were anesthetized, and their blood was taking out by the technique of retro-orbital puncture. Blood samples were collected into EDTA tubes and then centrifuged at 3,000 rpm for $10 \mathrm{~min}$ at $4^{\circ} \mathrm{C}$. Serum was separated and stored in freezer at $-20{ }^{\circ} \mathrm{C}$ until analysis.

Lipid profile:

All the parameters of serum total cholesterol (TC), total triglycerides (TG) and highdensity lipoprotein cholesterol (HDL-C) were measured by using reagents and kits available from (Merck KGaA, Darmstadt, Germany). The values of low-density lipoprotein cholesterol (LDL-C) and very low-density lipoprotein cholesterol (VLDLC) were calculated according to the equation of Friedwald $\boldsymbol{e t}$ al. (1972):

- $\mathrm{LDL}-\mathrm{C}(\mathrm{mg} / \mathrm{dl})=\mathrm{TC}-[(\mathrm{HDL}-\mathrm{C})+(\mathrm{VLDL}-\mathrm{C})]$

- $\operatorname{VLDL}-\mathrm{C}(\mathrm{mg} / \mathrm{dl})=\mathrm{TG} / 5$

STATISTICAL ANALYSIS

Statistical analyses were carried out according to SAS, (1996). Descriptive data are reported as means \pm standard deviation, and the results were analyzed statistically by a multiple comparison one-way analysis of variance, with the level of significance set at $\mathrm{p}<0.05$.

\section{RESULTS}

At the end of 8 weeks of experimentation after probiotics supplementation "Fermented milk" treatment, serum TC, TG, LDL-C, and VLDL-C of the group which fed on hypercholesterolemic diet "Control +ve" were significantly elevated compared with "control -ve" group $(44.02 \%, 52.03 \%, 65.51 \%$, and 52.04\% increases for TC, TG, LDL-C, and VLDL-cholesterol mean values, respectively, versus control group), whereas HDL- cholesterol level was decreased with $19.97 \%$ comparing with 


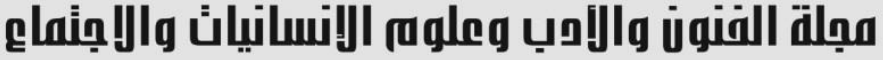 \\ Journal of Arts, Literature, Humanities and Social Sciences www.jalhss.com \\ Volume (54) July 2020 \\ العدد (54) يوليو 2020}

control group. On the other hand, probiotics supplementation fermented milk treatment clearly extenuate greater levels of these lipid parameters when compare with hypercholesterolemic diet treated group "control +ve". TC level was significantly declined by $25.11 \%$ of Probiotics-treated group, compared to the hypercholesterolemic diet -treated group. TG level was clearly inhibited by $21.71 \%$ of Probiotics-treated group, comparison by the hypercholesterolemic diet -treated group. LDL-cholesterol level was sharply dropped by $39.44 \%$ of Probiotics-treated group, compared to the hypercholesterolemic diet -treated group. VLDL-cholesterol level was clearly lowered by $21.72 \%$ of Probiotics-treated group, compared to the hypercholesterolemic diet -treated group. Conversely, HDL- cholesterol level was increased with 53.98\% of Probiotics-treated group, comparing with hypercholesterolemic diet -treated group, as shown in (Table 1).

Table 1. Influence of Probiotics Supplementation on the Lipid Profile of Hypercholesterolemic Rats.

\begin{tabular}{|c|c|c|c|c|c|}
\hline \multirow{2}{*}{ Groups } & \multicolumn{5}{|c|}{ Parameters } \\
\cline { 2 - 6 } & $\begin{array}{c}\mathrm{TC} \\
(\mathrm{mg} / \mathrm{dl})\end{array}$ & $\begin{array}{c}\mathrm{TG} \\
(\mathrm{mg} / \mathrm{dl})\end{array}$ & $\begin{array}{c}\text { HDL-C } \\
(\mathrm{mg} / \mathrm{dl})\end{array}$ & $\begin{array}{c}\text { LDL-C } \\
(\mathrm{mg} / \mathrm{dl})\end{array}$ & $\begin{array}{c}\text { VLDL-C } \\
(\mathrm{mg} / \mathrm{dl})\end{array}$ \\
\hline $\begin{array}{c}\text { Control }(- \\
\text { ve })\end{array}$ & $173.14 \pm 2.86 \mathrm{~b}$ & $105.42 \pm 2.72 \mathrm{c}$ & $40.21 \pm 1.75 \mathrm{c}$ & $111.85 \pm 2.50 \mathrm{~b}$ & $21.08 \pm 0.66 \mathrm{c}$ \\
\hline $\begin{array}{c}\text { Control }(+ \\
\text { ve })\end{array}$ & $249.35 \pm 3.50 \mathrm{a}$ & $160.27 \pm 3.33 \mathrm{a}$ & $32.18 \pm 1.77 \mathrm{a}$ & $185.12 \pm 3.64 \mathrm{a}$ & $32.05 \pm 1.20 \mathrm{a}$ \\
\hline $\begin{array}{c}\text { Probiotics } \\
\text { Bacteria }\end{array}$ & $186.75 \pm 2.25 \mathrm{~b}$ & $125.47 \pm 2.40 \mathrm{~b}$ & $49.55 \pm 1.28 \mathrm{~b}$ & $112.11 \pm 1.90 \mathrm{~b}$ & $25.09 \pm 0.42 \mathrm{~b}$ \\
\hline
\end{tabular}

$\mathrm{TC}=$ Total Cholesterol

$\mathrm{TG}=$ Triglycerides

HDL-C = High Density Lipoprotein-Cholesterol

LDL-C = Low Density Lipoprotein-Cholesterol

VLDL-C = Very Low Density Lipoprotein-Cholesterol

- Values expressed as mean \pm SD

- Values at the same column with different letters are significant at $\mathrm{P}<0.05$

\section{DISCUSSION}

The results of this study are in agreement with those of Pereira and Gibson, (2002) and Park, et al., (2007). They reported and suggested that, supplementation with Lactobacillus and Bifidobacterium reduced in the systemic levels of blood serum lipids for those suffering from hypercholesterolemia. Therefore, Probiotics as dietary supplement may inhibit the increasing of serum lipids under hypercholesterolemic diet-induced hypercholesterolemia, as well as it improved the HDL-cholesterol level.

The American Heart Association and American Stroke Association (AHA/ASA, 2020) published medical guidelines and scientific statements on various cardiovascular disease and stroke topics. The purpose of this AHA/ASA clinical data standards article is to publish consensus-based key data elements and definitions for 


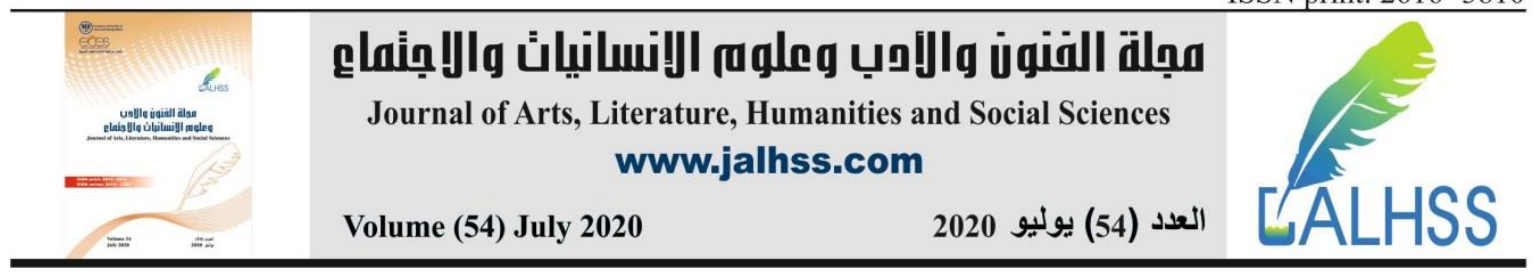

databases capturing information about coronary revascularization. They reported that, high-density lipoprotein, or HDL, is considered "good" cholesterol. It makes up 20-30 percent of a person's total cholesterol level and low-density lipoprotein, or LDL, is considered "bad" cholesterol and makes up 60-70 percent of the total cholesterol in the body, that confirm this study finding whereas, the percentage of HDL-C was 23.22 of the total cholesterol in the normal rats with feeding basal diet (-ve control group1), it reduced to 12.91 with feeding on hypercholesterolemic diet (+ve control group2), but the treatment with probiotics supplementation "fermented milk" resulted in improve this percentage up to 26.53 of the total cholesterol level (group 3). On the other hand, with regard to LDL-C, the percentage of LDL-C was 64.60 of the total cholesterol in the normal rats; it increased to 74.24 with feeding on hypercholesterolemic diet, but the treatment with probiotics supplementation "fermented milk" resulted in decrease this percentage to 60.03 of the total cholesterol level.

According to the American College of Cardiology/American Heart Association (ACC/AHA) Guideline on the Primary Prevention of Cardiovascular Disease (ACC/AHA, 2019); the calculation of cholesterol ratio is dividing the total cholesterol "TC" by the high-density lipoprotein "HDL" level. The optimal ratio is between 3.5 and 1. A higher ratio increases the risk of heart disease. A ratio below 3.5:1 is considered very well. They advised to keep the ratio below "5", with the ideal cholesterol ratio being " 3.5 ". Concerning to the results in this study, the ratio was 4.31 for group1 normal rats (-ve control) with feeding basal diet, while the ratio was 7.75 for group 2 (+ve control) with feeding on hypercholesterolemic diet, but the ratio was 3.77 for (group 3) with probiotics supplementation treatment. This indicates to the useful of fermented milk for improving the prevention of cardiovascular disease.

Jesús et al., (2009), mentioned to the risk categories and target levels for LDL$\mathrm{C} / \mathrm{HDL}-\mathrm{C}$ ratios as cardiovascular risk factors in clinical practice, in primary prevention, $>3.5$ as risk level and $<3.0$ as target level. The results of this study indicated clearly that the LDL-C/HDL-C ratios, were $2.78,5.75$, and 2.26 for group 1 which feeding basal diet, group 2 which feeding hypercholesterolemic diet, and group 3 with probiotics supplementation treatment respectively. These results supported the benefits of probiotics supplementation treatment for the prevention of cardiovascular risk.

\section{CONCLUSIONS}

The present study demonstrated that, the fermented milk "Rayeb" under studying which containing two genera of probiotics bacteria as bio-starters (Lactobacillus and Bifidobacterium) was effective in improving serum lipids in hypercholesterolemic rats, based on the previous studies which suggested that intestinal lactic acid bacteria have the potency to assimilate and bind cholesterol with the probiotic bacterial cells. From the results of this study, it is supposable that serum total cholesterol is lowered by inhibiting absorption in the intestine as a result of the assimilating and binding of cholesterol. These results show the potential of the probiotic bacteria effect of 


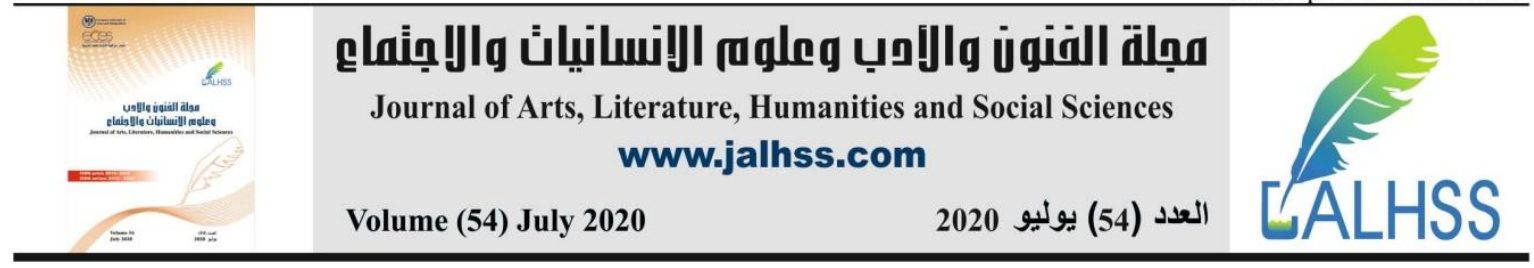

the dietary supplement fermented dairy products on serum cholesterol reduction and hence, cardiovascular risk.

Fermented dairy products with probiotic bacteria as dietary supplementation have been used to improve blood serum lipids of hypercholesterolemic rats. So, it can be given guidance to patients who develop hypercholesterolemia.

\section{RECOMMENDATIONS}

The present study recommends the following:

* It is attention to use probiotics bacteria as dietary supplementation in dairy products due to its benefits such as improving blood serum lipids of hypercholesterolemia and for the prevention of cardiovascular risk.

Educational programs could be designed to inform the public about the therapeutic benefits of probiotics as dietary supplementation in dairy products to improve blood serum lipids of hypercholesterolemia and for the prevention of cardiovascular risk.

More studies should be conducted on volunteer patients with hypercholesterolemia.

\section{REFERANCES}

1. ACC/AHA: Guideline on the Primary Prevention of Cardiovascular Disease: A Report of the American College of Cardiology/American Heart Association Task Force on Clinical Practice Guidelines. J Am Coll Cardiol. US. March 172019.

2. AHA/ACC: Key data elements and definition for coronary revascularization, medical guidelines and scientific statements. National Center, Dallas, TX, US. 2020. 3. Artham, S.M.; Lavie, C.J.; Milani, R.V.; Ventura, H.O.: The obesity paradox: Impact of obesity on the prevalence and prognosis of cardiovascular diseases. Post grad. Med. 2008, 120, 34-41. [CrossRef] [PubMed]

4. Davis, C.E.; Rifkind, B.M.; Brenner, H.; Gordon, D.J.: A single cholesterol measurement underestimates the risk of coronary heart disease. An empirical example from the Lipid Research Clinics Mortality Follow-up Study. JAMA. 1990, 264, 3044-3046. [CrossRef] [PubMed]

5. De Vrese M. and Schrezenmeir J.: Probiotics, prebiotics, and synbiotics. Adv Biochem Eng Biotechnol. 2008, 111: 1-66.

6. FAO/WHO "Food and Agriculture Organization / World Health Organization": Evaluation of Health and Nutritional Properties of Powder Milk and Live Lactic Acid Bacteria; Food and Agriculture Organization of the United Nations and World Health Organization Expert Consultation Report; FAO/WHO: 2001. Rome, Italy.

7. Friedewald, W.T., Levy, R.I. and Fredrickson, D.S: Estimation of concentration of LDL-cholesterol in plasma, without use of preparative ultracentrifuge. Clinical Chem. 1972, 18: 499-502.

8. Jesús Millán, Xavier Pintó, Anna Muñoz, Manuel Zúñiga, Joan Rubiés-Prat, Luis Felipe Pallardo, Luis Masana, Alipio Mangas, Antonio Hernández-Mijares, Pedro González-Santos, Juan F Ascaso, and Juan Pedro-Botet: Lipoprotein ratios: 


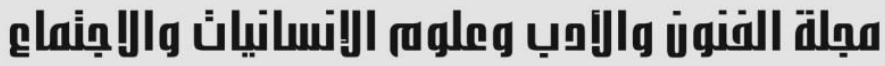 \\ Journal of Arts, Literature, Humanities and Social Sciences www.jalhss.com

Physiological significance and clinical usefulness in cardiovascular prevention. Vasc Health Risk Manag. 2009, 5: 757-765.

9. Park, YH; Kim, JG; Shin, YW; Kim, SH. and Whang, KY.: Effect of dietary inclusion of Lactobacillus acidophilus ATCC 43121 on cholesterol metabolism in rats. J Microbiol Biotechnol. 2007, Vol. 17, No.4, 655-62.

10. Pereira D.I. and Gibson G.R.: Effect of consumption of probiotics and prebiotics on serum lipid levels in humans. Crit Rev Biol. 2002, vol.37, No 4, 25981.

11. Reeves PG, Nielsen FH, Fahey GC.: AIN-93 purified diets for laboratory rodents: final report of the American Institute of Nutrition ad hoc writing committee on the reformulation of the AIN-76A rodent diet. J Nutr. 1993, 123:1939-51.

12. SAS: Statistical Analysis System, User guide: statistics. SAS Institute Inc. Editors, Cary, NC. 1996.

13. Sanders M.E.: Probiotics: definition, sources, selection, and uses. Clin Infect Dis. 2008, 1; 46, Supp 12, 58-61.

14. Xiao, J.Z.; Kondo, S.; Takahashi, N.; Miyaji, K.; Oshida, K.; Hiramatsu, A.; Iwatsuki, K.; Kokubo, S.; Hosono, A.: Effects of milk products fermented by Bifidobacterium longum on blood lipids in rats and healthy adult male volunteers. J. Dairy Sci. 2003, 86, 2452-2461. [CrossRef]

15. Zulet, MA; Barber, A; Garcin, H; Higueret, P. and Martinez, A.: Alterations in carbohydrate and lipid metabolism induced by a diet rich in coconut oil and cholesterol in a rat model. J. AM. Coll. Nutr.1999, Vol. 18, No. 1, 36-42. 